\title{
Short communication: Evaluation of milk urea nitrogen as a management tool to reduce ammonia emissions from dairy farms
}

\author{
J. M. Powell, ${ }^{\star 1}$ M. A. Wattiaux, $\dagger$ and G. A. Broderick* \\ *USDA-Agricultural Research Service, US Dairy Forage Research Center, Madison, WI 53706 \\ †Department of Dairy Science, University of Wisconsin-Madison, Madison 53706
}

\begin{abstract}
The purpose of this study was to compile and evaluate relationships between feed nitrogen $(\mathrm{N})$ intake, milk urea $\mathrm{N}$ (MUN), urinary urea $\mathrm{N}$ (UUN), and ammonia $\left(\mathrm{NH}_{3}\right)$ emissions from dairy farms to aid policy development. Regression relationships between MUN, UUN, and $\mathrm{NH}_{3}$ emissions were compiled from studies conducted in Wisconsin, California, and the Netherlands. Relative reductions in $\mathrm{NH}_{3}$ emissions were calculated as percentage decreases in $\mathrm{NH}_{3}$ emissions associated with a baseline MUN level of $14 \mathrm{mg} / \mathrm{dL}$ (prevailing industry average). For 3 studies with cows in stanchion barns, relative $\mathrm{NH}_{3}$ emission reductions of 10.3 to $28.2 \%$ were obtained when MUN declined from 14 to $10 \mathrm{mg} / \mathrm{dL}$. Similarly, analyses of 2 freestall studies provided relative $\mathrm{NH}_{3}$ emission reductions of 10.5 to $33.7 \%$ when MUN levels declined from 14 to $10 \mathrm{mg} / \mathrm{dL}$. The relative reductions in $\mathrm{NH}_{3}$ emissions from both stanchion and freestall barns can be associated directly with reductions in UUN excretion, which can be determined using MUN. The results of this study may help create new awareness, and perhaps eventual industry-based incentives, for management practices that enhance feed $\mathrm{N}$ use efficiency and reduce MUN, UUN, and $\mathrm{NH}_{3}$ emissions from dairy farms.
\end{abstract}

Key words: dietary crude protein, milk urea nitrogen, urinary urea nitrogen, ammonia emissions

\section{Short Communication}

Dairy cows excrete urea $\mathrm{N}$ in urine, which is a source of $\mathrm{NH}_{3}$ emission into the atmosphere. Of the total feed $\mathrm{N}$ consumed by lactating cows on commercial dairy farms, a general range of 20 to $35 \%$ is secreted in milk (Jonker et al., 2002; Chase, 2004; Powell et al., 2010), and the remainder is excreted about equally in feces and urine (Kebreab et al., 2010). Ration formulation may influence not only feed $\mathrm{N}$ transformation into milk

Received April 22, 2011.

Accepted June 23, 2011

${ }^{1}$ Corresponding author: mark.powell@ars.usda.gov but also the proportion of $\mathrm{N}$ excreted in feces and urine (Wattiaux and Karg, 2004). As dietary CP increases and $\mathrm{N}$ intake exceeds requirement, feed $\mathrm{N}$ use efficiency declines and the excretion of urinary $\mathrm{N}$ increases without gains in milk N secretion (Broderick and Clayton, 1997; Nousiainen et al., 2004).

Under prevailing feeding practices in the Midwest region of the United States, a well-balanced diet that contains about $164 \mathrm{~g}$ of $\mathrm{CP} / \mathrm{kg}$ of DM maximizes milk production and minimizes urinary urea N (UUN) excretion by dairy cows (Broderick, 2003, 2009). After excretion, urea $\mathrm{N}$ comprises 55 to $82 \%$ of total urinary $\mathrm{N}$ when dietary CP ranges from 135 to $194 \mathrm{~g}$ of $\mathrm{CP} / \mathrm{kg}$ of DM (Olmos Colmenero and Broderick, 2006). Upon excretion, urea $\mathrm{N}$ is hydrolyzed rapidly to ammonium $\left(\mathrm{NH}_{4}{ }^{+}\right)$by urease enzymes found in feces and soil. In solution, $\mathrm{NH}_{4}{ }^{+}$is in a $\mathrm{pH}$-dependent equilibrium with $\mathrm{NH}_{3}$, and the latter may be lost to the atmosphere depending on temperature, air velocity, and less important factors. Thus, the increase in UUN excretion due to excessive feeding of dietary $\mathrm{CP}$ increases $\mathrm{NH}_{3}$ emissions during the collection, storage, and land application of manure (see Rotz, 2004; Misselbrook et al., 2005; Powell et al., 2008; Arriaga et al., 2010).

Urea is the main form of excretory $\mathrm{N}$ by mammals (Rook and Thomas, 1985). Its synthesis occurs primarily in the liver from the $\mathrm{NH}_{3}$ produced in splanchnic tissues (LaPierre et al., 2005). High BUN concentrations have long been known to be indicative of inefficient utilization of dietary CP by ruminants (Lewis, 1957). Urea equilibrates rapidly throughout body fluids, including milk, so concentrations of MUN reflect those of BUN (Gustafsson and Palmquist, 1993). In addition, urea in body fluids is related to protein catabolism (Botts et al., 1979) and the inefficiency of $\mathrm{N}$ utilization in animal tissue (Jonker et al., 1998; Nousiainen et al., 2004). Furthermore, metabolizable protein that is catabolized for energy contributes to the body urea pool. Thus, MUN can serve as an index of feed $\mathrm{N}$ utilization efficiency in the lactating dairy cow (Broderick and Clayton, 1997).

Milk urea $\mathrm{N}$ has been measured extensively on commercial dairy farms to monitor and adjust dietary $\mathrm{CP}$ levels. Using MUN as a tool to fine-tune ration formula- 
tion can enhance feed $\mathrm{N}$ use efficiency and decrease the excretion of $\mathrm{N}$ in urine (Kohn, 2007). The accuracy of MUN for predicting ration $\mathrm{CP}$ levels and urinary $\mathrm{N}$ excretion has been validated with extensive farm data sets in the United States (Jonker et al., 1998) and Europe (Nousiainen et al., 2004). On typical confinement dairy farms in the United States, MUN concentrations of bulk tank Holstein milk samples usually range from 11 to $18 \mathrm{mg} / \mathrm{dL}$ (Hutjens, 1998), with peak MUN concentrations occurring during early lactation (Kohn, 2007).

Over the past decade, in response to concerns related to the impact of $\mathrm{NH}_{3}$ emissions on human and ecological health, much information has been published on positive relationships between dietary $\mathrm{CP}$ concentration, MUN, and urinary $\mathrm{N}$ excretion (Nousiainen et al., 2004; Burgos et al., 2007; Kohn, 2007; Kebreab et al., 2010). A recent compilation of data from 8 experiments (32 dietary treatments) conducted in Wisconsin (Wattiaux et al., 2011) depicts typical relationships between MUN, dietary CP concentrations, and UUN excretion (Figure 1). Information is also available on relationships between UUN excretion and $\mathrm{NH}_{3}$ emission from dairy barns (Smits et al., 1995; Monteny et al., 2002; Cassel et al., 2005; Powell et al., 2008). Only a few studies have linked MUN, UUN excretion, and $\mathrm{NH}_{3}$ emissions (Frank and Swensson, 2002; van Duinkerken et al., 2005, 2011; Powell et al., 2008; Burgos et al., 2010). Very few data are available on direct relationships between MUN and $\mathrm{NH}_{3}$ emission. The purpose of this communication is to provide a general overview of the relationships among dietary CP, MUN, UUN excretion, and $\mathrm{NH}_{3}$ emissions, and to examine the potential use of MUN in policy development and as a tool to create awareness and incentives that will lead to beneficial feeding practices and the reduction of UUN excretion and $\mathrm{NH}_{3}$ emissions from dairy farms.

To assist poultry and livestock producers in their compliance with Wisconsin's Air Toxics Rule (NR 445, Control of Hazardous Pollutants), the Wisconsin Department of Natural Resources (WI-DNR) recently proposed "Beneficial Management Practices for Mitigating Hazardous Air Emissions from Animal Waste in Wisconsin" (WI-DNR, 2010). The technical advisory group tasked to write that report relied on literature reviews and their knowledge of animal agriculture in Wisconsin to designate "standard" prevalent practices that could be used as benchmarks for calculating relative reductions in $\mathrm{NH}_{3}$ (and hydrogen sulfide) emissions due to the adoption of "beneficial" management practices. Therefore, to assess the impacts of beneficial feed practices, a MUN value of $14 \mathrm{mg} / \mathrm{dL}$ was selected as an industry-average benchmark, and a range of MUN values from 14 to $10 \mathrm{mg} / \mathrm{dL}$ was selected to calculate relative reductions in $\mathrm{NH}_{3}$ emissions associated with reductions in MUN.

Using half a million DHIA records, the analysis of Wattiaux et al. (2005) determined that milk protein yields $(\mathrm{kg} / \mathrm{d}$ per cow) by Holstein dairy cows were not penalized within the MUN range of 14 to $10 \mathrm{mg} / \mathrm{dL}$. Results of controlled nutritional studies (Broderick and Clayton, 1997) and evaluation of a large DHIA database (Wattiaux et al., 2005) indicated that, under typical feeding practices in the Midwest, feed $\mathrm{N}$ use efficiency increased linearly as MUN levels declined from 24 to $10 \mathrm{mg} / \mathrm{dL}$. Based on the selected benchmark MUN concentration of $14 \mathrm{mg} / \mathrm{dL}$ and the analyses contained in this communication, the Wisconsin Advisory Group recommended that a $10 \% \mathrm{NH}_{3}$ emission reduction credit be given for farms having monthly average bulk-tank MUN concentrations of 10 to $12 \mathrm{mg} / \mathrm{dL}$, and a $20 \%$ reduction credit be provided to farms that kept monthly MUN concentrations < $10 \mathrm{mg} / \mathrm{dL}$ (WI-DNR, 2010).

Our analyses encompassed about a 10-fold difference in $\mathrm{NH}_{3}$ emission rates (from 10 to $95 \mathrm{~g} / \mathrm{d}$ per cow) from 5 studies in the 3 geographic locations (Table 1). Lowest $\mathrm{NH}_{3}$ emissions (an average range of approximately 10 to $14 \mathrm{~g} / \mathrm{d}$ per cow) were recorded in the 2 stanchion barn studies in Wisconsin, intermediate emissions (22 to $28 \mathrm{~g} / \mathrm{d}$ per cow) in the stanchion barn study in the Netherlands, followed by the highest emissions from freestalls in Wisconsin (51 to $77 \mathrm{~g} / \mathrm{d}$ per cow) and California (75 to $94 \mathrm{~g} / \mathrm{d}$ per cow). Many factors explain this wide range in $\mathrm{NH}_{3}$ emissions, including differences in the type and amount of dietary $\mathrm{CP}$ fed to the lactating cows, temperatures, air flow, and measurement techniques [cows in stanchion chambers in Wisconsin

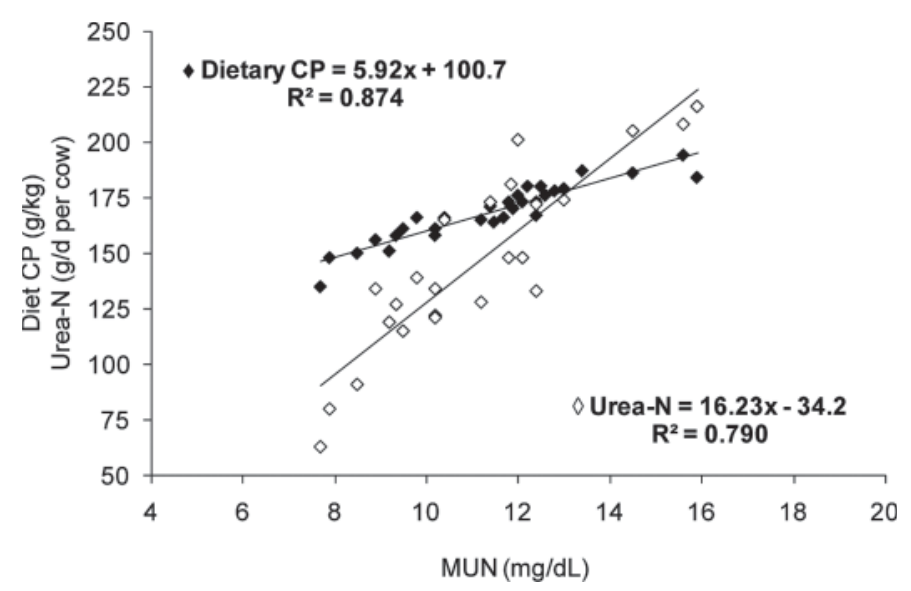

Figure 1. Relationships between MUN, dietary CP, and excretion of urea $\mathrm{N}$ in urine. Data are summary data from 9 trials that included 37 different dietary treatments; trials were conducted between 2003 and 2009 and included diets typical of the Midwestern United States. Adapted from Wattiaux et al. (2011). 
(Powell et al., 2008; Aguerre et al., 2010); $\mathrm{SF}_{6}$ technique applied to stanchion barns in the Netherlands (van Duinkerken et al., 2011); excreta added to freestall flux chambers in Wisconsin (Misselbrook et al., 2005); and excreta added to freestall flux chambers in California (Burgos et al., 2010)]. In addition, lower $\mathrm{NH}_{3}$ emissions from stanchions than from freestall barns occur because of differences in bedding materials (Misselbrook and Powell, 2005), the emitting surface areas, the degree of feces and urine mixing during manure removal from barns (Monteny and Erisman, 1998; Pedersen, 2006), and other less important factors.

The relative $\mathrm{NH}_{3}$ emission reductions associated with declines in MUN were similar across barn types and geographic locations (Table 1). For the 3 stanchion barn studies in Wisconsin and the Netherlands, an av- erage $\mathrm{NH}_{3}$ emission reduction of $12.4 \%$ was associated with a decrease in MUN from 14 to $12 \mathrm{mg} / \mathrm{dL}$, and an average emission reduction of $24.9 \%$ was associated with a decline in MUN from 14 to $10 \mathrm{mg} / \mathrm{dL}$. For the 2 freestalls in Wisconsin and California, an average $\mathrm{NH}_{3}$ emission reduction of $13.5 \%$ was associated with a decrease in MUN from 14 to $12 \mathrm{mg} / \mathrm{dL}$, and an average emission reduction of $27.4 \%$ was obtained when MUN decreased from 14 to $10 \mathrm{mg} / \mathrm{dL}$. Possible reasons why MUN was not a better predictor of $\mathrm{NH}_{3}$ emissions in the 2 Wisconsin stanchion studies $\left(\mathrm{R}^{2}\right.$ of 0.27 and 0.51 ; Table 1 ) were related to the use of very different cows (parity, DIM) for each trial; the use of weighted, individual MUN rather than bulk-tank MUN; and great differences in temperature and relative humidity (Powell et al., 2008; Aguerre et al., 2011). Nevertheless,

Table 1. Relationships between $\mathrm{MUN}, \mathrm{NH}_{3}$ emissions, and relative reduction in $\mathrm{NH}_{3}$ emissions from dairy barns

\begin{tabular}{|c|c|c|c|c|}
\hline Location & $\begin{array}{l}\text { Barn } \\
\text { type }\end{array}$ & $\begin{array}{c}\text { MUN } \\
(\mathrm{mg} / \mathrm{dL})\end{array}$ & $\begin{array}{l}\mathrm{NH}_{3} \text { emission } \\
(\mathrm{g} / \mathrm{d} \text { per cow })\end{array}$ & $\begin{array}{c}\mathrm{NH}_{3} \text { reduction } \\
\text { (\% from baseline } \\
\text { MUN of } 14 \mathrm{mg} / \mathrm{dL} \text { ) }\end{array}$ \\
\hline \multirow[t]{3}{*}{ Wisconsin } & \multirow[t]{3}{*}{ Stanchion $^{1}$} & 14 & 14.2 & 0 \\
\hline & & 12 & 12.2 & 14.1 \\
\hline & & 10 & 10.2 & 28.2 \\
\hline \multirow[t]{3}{*}{ Wisconsin } & \multirow[t]{3}{*}{ Stanchion $^{2}$} & 14 & 13.3 & 0 \\
\hline & & 12 & 11.6 & 12.8 \\
\hline & & 10 & 9.9 & 25.6 \\
\hline \multirow[t]{3}{*}{ The Netherlands } & \multirow{3}{*}{ Stanchion $^{3}$} & 14 & 28.2 & 0 \\
\hline & & 12 & 25.3 & 10.3 \\
\hline & & 10 & 22.3 & 20.9 \\
\hline \multirow[t]{3}{*}{ Wisconsin } & \multirow{3}{*}{ Freestall $^{4}$} & 14 & 77.2 & 0 \\
\hline & & 12 & 64.4 & 16.6 \\
\hline & & 10 & 51.2 & 33.7 \\
\hline \multirow[t]{3}{*}{ California } & \multirow[t]{3}{*}{ Freestall $^{5}$} & 14 & 95.4 & 0 \\
\hline & & 12 & 85.4 & 10.5 \\
\hline & & 10 & 75.3 & 21.1 \\
\hline
\end{tabular}

${ }^{1}$ Derived from 3 barn chamber studies; each study had 16 dairy cows, 4 diets, 4 cows per diet, 4 replicates per diet (Powell et al., 2008). Dietary CP from 157 to $212 \mathrm{~g} / \mathrm{kg}$; MUN from 5.6 to $24.3 \mathrm{mg} / \mathrm{dL} ; \mathrm{NH}_{3}$ emissions from 2.5 to $36.7 \mathrm{~g} / \mathrm{d}$ per cow; temperatures from -5.1 to $27.9^{\circ} \mathrm{C}$. Relationship between MUN (x, in $\mathrm{mg} / \mathrm{dL}$ ) and $\mathrm{NH}_{3}-\mathrm{N}$ (y, in $\mathrm{g} / \mathrm{d}$ per cow): $\mathrm{y}=0.991 \mathrm{x}+0.33 ; \mathrm{R}^{2}=0.27$.

${ }^{2}$ Derived from a barn chamber study with 16 dairy cows, 4 diets, 4 cows per diet, 4 replicates per diet (Aguerre et al., 2011). Dietary CP from 161 to $162 \mathrm{~g} / \mathrm{kg}$; MUN from 14.2 to $16.1 \mathrm{mg} / \mathrm{dL} ; \mathrm{NH}_{3}$ emissions from 13.0 to $15.1 \mathrm{~g} / \mathrm{d}$ per cow; temperatures from 19.3 to $36.7^{\circ} \mathrm{C}$. Relationship between MUN (x, in mg/dL) and $\mathrm{NH}_{3}-\mathrm{N}(\mathrm{y}$, in $\mathrm{g} / \mathrm{d}$ per cow): $\mathrm{y}=0.866 \mathrm{x}+1.21 ; \mathrm{R}^{2}=0.51$.

${ }^{3}$ Sulfur hexafluoride $\left(\mathrm{SF}_{6}\right)$ tracer gas used in stanchion barns, 52 cows, 9 diets (3 basal diets, each diet adjusted with urea to create different MUN levels). Milk urea $\mathrm{N}$ from 7.2 to $24.1 \mathrm{mg} / \mathrm{dL} ; \mathrm{NH}_{3}$ emissions from 22.3 to $28.2 \mathrm{~g} / \mathrm{d}$ per cow; temperatures from approximately 10 to $25^{\circ} \mathrm{C}$. Extrapolated from algorithm developed by van Duinkerken et al. (2011).

${ }^{4}$ Combined analyses from 2 studies: Study 1: Relationships between MUN and urea N excretion depicted in Figure 1. Study 2: Flux chamber studies conducted by Misselbrook et al. (2005). Approximately $40 \%$ of urea $\mathrm{N}$ was emitted as $\mathrm{NH}_{3}$ during the $24 \mathrm{~h}$ after manure application to flux chambers. Dietary $\mathrm{CP}$ from 136 to $194 \mathrm{~g} / \mathrm{kg} ; \mathrm{NH}_{3}$ emission equivalents from 38 to $90 \mathrm{~g} / \mathrm{d}$ per cow; constant temperature of $15^{\circ} \mathrm{C}$. Combination of results from study 1 and study 2: at MUN of $14 \mathrm{mg} / \mathrm{dL}$, of the $193 \mathrm{~g}$ of urea N excreted/d per cow, $77.2 \mathrm{~g}$ (i.e., $40 \%$ ) would be emitted as $\mathrm{NH}_{3}$; at MUN of $12 \mathrm{mg} / \mathrm{dL}$ and MUN of $10 \mathrm{mg} / \mathrm{dL}, 161$ and $128 \mathrm{~g} / \mathrm{d}$ of urea $\mathrm{N}$ would be excreted, respectively, of which 64.4 and $51.2 \mathrm{~g} / \mathrm{d}$ per cow would be emitted as $\mathrm{NH}_{3}$. If MUN of 14 $\mathrm{mg} / \mathrm{dL}$ is baseline, then relative $\mathrm{NH}_{3}$ emission reductions at MUN of $12 \mathrm{mg} / \mathrm{dL}$ would be [(77.2 - 64.4)/77.2] $\times 100=16.6 \%$, and relative $\mathrm{NH}_{3}$ emission reductions at MUN of $10 \mathrm{mg} / \mathrm{dL}$ would be $[(77.2-51.2) / 77.2] \times$ $100=33.7 \%$.

${ }^{5}$ Extrapolated from flux chamber studies of Burgos et al. (2010). Dietary CP from 151 to $217 \mathrm{~g} / \mathrm{kg}$; MUN from 6.0 to $32.0 \mathrm{mg} / \mathrm{dL} ; \mathrm{NH}_{3}$ emission equivalents from 56.8 to $149.1 \mathrm{~g} / \mathrm{d}$ per cow; constant temperatures of $22.5^{\circ} \mathrm{C}$. Relationship between MUN (x, in $\mathrm{mg} / \mathrm{dL}$ ) and $\mathrm{NH}_{3}-\mathrm{N}(\mathrm{y}$, in $\mathrm{g} / \mathrm{d}$ per cow $): \mathrm{y}=5.03 \mathrm{x}+25.0 ; \mathrm{R}^{2}=0.85$. 
the use of these 2 Wisconsin algorithms to calculate average $\mathrm{NH}_{3}$ emissions rates provided relative $\mathrm{NH}_{3}$ emission reductions that were similar to each other and to the relative $\mathrm{NH}_{3}$ emission reductions calculated from the other stanchion study in the Netherlands and the 2 freestall studies in Wisconsin and California (Table 1).

The overall range in relative $\mathrm{NH}_{3}$ reductions (from 10.3 to $16.6 \%$ ) when MUN levels declined from 14 to $12 \mathrm{mg} / \mathrm{dL}$ and the overall range in relative $\mathrm{NH}_{3}$ reductions (from 20.9 to $33.7 \%$ ) when MUN levels declined from 14 to $10 \mathrm{mg} / \mathrm{dL}$ indicate that the general $\mathrm{NH}_{3}$ reduction credits of 10 and $20 \%$ proposed by the Wisconsin Advisory Group (WI-DNR, 2010) would be conservative for MUN declines from 14 to $<10 \mathrm{mg} / \mathrm{dL}$. Ammonia emission reductions associated with declines in MUN may be even greater if MUN levels exceed 14 $\mathrm{mg} / \mathrm{dL}$. For example, an $\mathrm{N}$ balance study of a freestall in Wisconsin determined $\mathrm{NH}_{3}$ reductions of $13.4 \%$ for each unit decrease in MUN from 16.7 to $14.7 \mathrm{mg} / \mathrm{dL}$ (Aguerre et al., 2010), and a stanchion study in the Netherlands using $\mathrm{SF}_{6}$ determined a $35 \%$ reduction when MUN decreased from 19.2 to $14.4 \mathrm{mg} / \mathrm{dL}$ (van Duinkerken et al., 2010).

The wide range of barn floor types, dietary CP, MUN, temperatures, and emission methods used in the present analyses (Table 1), as well as the correspondence among study results, suggests that MUN may be an effective tool for benchmarking and evaluating the effects of feeding practices on relative $\mathrm{NH}_{3}$ emissions across a wide range of dairy system types in various geographic locations. The information used for this study's calculations (Table 1) was from feeding trials conducted with Holstein dairy cows. The relationships between dietary $\mathrm{CP}$, MUN, UUN excretion, and $\mathrm{NH}_{3}$ emissions will likely differ from those of other dairy breeds, such as Jersey and Brown Swiss (Wattiaux et al., 2005).

The currently used infrared assay for rapid determination of MUN in bulk tank samples from commercial dairy farms offers the possibility of extending MUN results to create widespread awareness of the linkages between excessive $\mathrm{CP}$ concentrations in dairy rations and increases in MUN secretion, UUN excretion, and $\mathrm{NH}_{3}$ emissions from dairy farms. Controversy exists, however, surrounding determinations of $\mathrm{NH}_{3}$ and other gaseous emissions from agricultural systems. The debate centers on different perceptions of required precision in emission measurements. Noninterference techniques (e.g., open-path lasers, $\mathrm{N}$ mass balance studies) are deemed necessary for precise determinations of actual emission factors (Harper et al., 2010). However, chambers of all types have been used successfully for determinations of relative differences in gaseous emissions due to treatments (Rochette and Bertrand, 2010).
Results of the present study (Table 1) indicate that chambers can be used to determine relative effectiveness of management practices (e.g., improved feeding) on reducing $\mathrm{NH}_{3}$ (and other gaseous) emissions from dairy farms.

The relative $\mathrm{NH}_{3}$ emission reductions associated with declines in MUN (Table 1) may offer practical, straightforward approaches for creating new awareness, and perhaps for structuring incentives that motivate adoption of improved feeding practices. Whether the 2 to $4 \mathrm{mg} / \mathrm{dL}$ reduction in MUN creates a 10 to $20 \%$ reduction in $\mathrm{NH}_{3}$ emission (Table 1; WI-DNR, 2010) is not critically important. The positive relationships between dietary $\mathrm{CP}, \mathrm{MUN}$, UUN, and $\mathrm{NH}_{3}$ emissions are scientifically sound, and the uniformity in associations between relative $\mathrm{NH}_{3}$ emission reduction as MUN declines across various dairy system types could be used to motivate change (improved feeding practices) toward desired outcomes (reduced $\mathrm{NH}_{3}$ emission). Eventually, the dairy industry may be willing to adopt an incentive structure whereby premiums are offered to dairy producers for milk shipped with the desired range of MUN values. This would be a relatively simple way to move the industry in a positive direction toward abatement of $\mathrm{NH}_{3}$ emissions and environmental enhancement.

\section{REFERENCES}

Aguerre, M. J., M. A. Wattiaux, T. Hunt, and B. R. Larget. 2010. Effect of dietary crude protein on ammonia-N emission measured by herd nitrogen mass balance in a free-stall dairy barn managed under farm-like conditions. Animal 4:1390-1400.

Aguerre, M. J., M. A. Wattiaux, J. M. Powell, and G. A. Broderick. 2011. Effect of forage to concentrate ratio in dairy cow diets on emission of methane, carbon dioxide and ammonia, lactation performance and manure excretion. J. Dairy Sci. 94:3081-3093. doi:10.3168/jds.2010-4011.

Arriaga, H., G. Salcedo, L. Martínez-Suller, S. Calsamigli, and P. Merino. 2010. Effect of dietary crude protein modification on ammonia and nitrous oxide concentration on a tie-stall dairy barn floor. J. Dairy Sci. 93:3158-3165.

Botts, R. L., R. W. Hemken, and L. S. Bull. 1979. Protein reserves in the lactating dairy cow. J. Dairy Sci. 62:433-440.

Broderick, G. A. 2003. Effects of varying dietary protein and energy levels on the production of lactating dairy cows. J. Dairy Sci. 86:1370-1381.

Broderick, G. A. 2009. New perspectives on the efficiency of nitrogen use in ruminants. Pages $165-178$ in II Simposio Internacional Avancos em Techicas de Pesquisa em Nutricao de Ruminantes. L. F. Prada e Silva and F. P. Rennó, ed. University of Viçosa, Viçosa, Brazil.

Broderick, G. A., and M. K. Clayton. 1997. A statistical evaluation of animal and nutritional factors influencing concentrations of milk urea nitrogen. J. Dairy Sci. 80:2964-2971.

Burgos, S. A., N. M. Embertson, Y. Zhao, F. M. Mitloehner, E. J. DePeters, and J. G. Fadel. 2010. Prediction of ammonia emissions from dairy cattle manure based on milk urea nitrogen: Relationship of milk urea nitrogen to ammonia emissions. J. Dairy Sci. 93:2377-2386.

Burgos, S. A., J. G. Fadal, and E. J. DePeters. 2007. Prediction of ammonia emissions from dairy cattle manure based on milk urea nitrogen excretion: Relation of milk urea nitrogen to urine urea nitrogen excretion. J. Dairy Sci. 90:5499-5508. 
Cassel, T., L. Ashbaugh, and R. Flocchini. 2005. Ammonia emission factors for open-lot dairies: Direct measurements and estimation by nitrogen intake. J. Air Waste Manag. Assoc. 55:826-833.

Chase, L. E. 2004. Estimated nitrogen excretion in 46 commercial dairy herds in New York. Accessed June 24, 2011. http://www. dairyn.cornell.edu/pages/40dairy/410utilization/416excretion. shtml.

Gustafsson, A. H., and D. L. Palmquist. 1993. Diurnal variation of rumen ammonia, serum urea, and milk urea in dairy cows at high and low yields. J. Dairy Sci. 76:475-484.

Harper, L. A., T. K. Flesch, and J. D. Wilson. 2010. Micrometeorological techniques for measurement of greenhouse gas emissions from ruminant animal production. Pages 78-79 in Proc. 4th Greenhouse Gasses and Animal Agriculture Conference, Banff, Canada. E. J. McGeough and S. M. McGinn, ed. Agriculture and Agri-Food Canada, Ottawa, ON, Canada.

Hutjens, M. J. 1998. MUN as a management tool. Illini DairyNet Papers. University of Illinois Extension, Champaign. Accessed June 24, 2011. http://www.livestocktrail.uiuc.edu/dairynet/paperDisplay.cfm?ContentID $=233$.

Jonker, J. S., R. A. Kohn, and R. A. Erdman. 1998. Using milk urea nitrogen to predict nitrogen excretion and utilization efficiency in lactating dairy cows. J. Dairy Sci. 81:2681-2692.

Jonker, J. S., R. A. Kohn, and J. High. 2002. Dairy herd management practices that impact nitrogen utilization efficiency. J. Dairy Sci. $85: 1218-1226$

Kebreab, E., A. B. Strathe, J. Dijkstra, J. A. N. Mills, C. K. Reynolds, L. A. Crompton, T. Yan, and J. France. 2010. Energy and protein interactions and their effects on nitrogen excretion in dairy cows. Pages 417-426 in Proc. 3rd European Association for Animal Production (EAAP) International Symposium on Energy and Protein Metabolism and Nutrition, Parma, Italy. G. Matteo Crovetto, ed. EAPP publication No. 127. Wageningen Academic Publishers, Wageningen, the Netherlands.

Kohn, R. 2007. Use of milk or blood urea nitrogen to identify feed management inefficiencies and estimate nitrogen excretion by dairy cattle and other animals. Florida Ruminant Nutrition Symposium, Gainesville, FL. University of Florida, Gainesville.

LaPierre, H., R. Berthiaume, G. Raggio, M. C. Thivierge, L. Doepel, D. Pacheco, P. Dubreui, and G. E. Lobley. 2005. The route of absorbed nitrogen into milk protein. Anim. Sci. 80:11-22.

Lewis, D. 1957. Blood-urea concentration in relation to protein utilization in the ruminant. J. Agric. Sci. (Camb.) 48:438-447.

Misselbrook, T. H., and J. M. Powell. 2005. Influence of bedding material on ammonia emissions from cattle excreta. J. Dairy Sci. 88:4304-4312.

Misselbrook, T. H., J. M. Powell, G. A. Broderick, and J. H. Grabber. 2005. Dietary manipulation in dairy cattle: Laboratory experiments to assess the influence on ammonia emissions. J. Dairy Sci. 88:1765-1777.

Monteny, G. J., and J. W. Erisman. 1998. Ammonia emission from dairy cow buildings: A review of measurement techniques, influencing factors and possibilities for reduction. Neth. J. Agric. Sci. $46: 225-247$.

Monteny, G. J., M. C. J. Smits, G. van Duinkerken, H. Mollenhorst, and I. J. M. De Boer. 2002. Prediction of ammonia emissions from dairy barns using feed characteristics. Part II: Relationships between urinary urea concentration and ammonia emission. J. Dairy Sci. 85:3389-3394.
Nousiainen, J., K. J. Shingfield, and P. Huhtanen. 2004. Evaluation of milk urea nitrogen as diagnostic of protein feeding. J. Dairy Sci. $87: 386-398$.

Olmos Colmenero, J. J., and G. A. Broderick. 2006. Effect of dietary crude protein concentration on milk production and nitrogen utilization in lactating dairy cows. J. Dairy Sci. 89:1704-1712.

Pedersen, S. 2006. Agricultural best management practices in Denmark. Pages 56-67 in Proc. Workshop on Agricultural Air Quality: State of the Science, Potomac, MD. V. P. Aneja, W. H. Schlesinger, R. Knighton, G. Jennings, D. Niyogi, W. Gilliam, and C.S Duke, ed. Dept. Comm. Serv., North Carolina State University, Raleigh.

Powell, J. M., G. A. Broderick, and T. H. Misselbrook. 2008. Seasonal diet affects ammonia emissions from tie-stall dairy barns. J. Dairy Sci. 91:857-869.

Powell, J. M., C. J. P. Gourley, C. A. Rotz, and D. M. Weaver. 2010 Nitrogen use efficiency: A potential performance indicator and policy tool for dairy farms. Environ. Sci. Policy 13:217-228.

Rochette, P., and N. Bertrand. 2010. Recognizing the strengths and weaknesses of chamber nitrous oxide measurements. Page 79 in Proc. 4th Greenhouse Gasses and Animal Agriculture Conference. E. J. McGeough and S. M. McGinn, ed. Banff, Canada. Agriculture and Agri-Food Canada, Ottawa, ON, Canada.

Rook, J. A. F., and P. C. Thomas. 1985. Milk secretion and its nutritional regulation. Ch. 8 in Nutritional Physiology of Farm Animals. J. A. F. Rook and P. C. Thomas, ed. Longman Group Ltd. London, UK.

Rotz, C. A. 2004. Management to reduce nitrogen losses in animal production. J. Anim. Sci. 82(E. Suppl.):E119-E137.

Smits, M. C. J., H. Valk, A. Elzing, and A. Keen. 1995. Effect of protein nutrition on ammonia emission from a cubicle house for dairy cattle. Livest. Prod. Sci. 44:147-156.

van Duinkerken, G., G. Andrè, M. C. J. Smits, G. J. Monteny, and L. B. J. Šebek. 2005. Effect of rumen-degradable protein balance and forage type on bulk milk urea concentration and emission of ammonia from dairy cow houses. J. Dairy Sci. 88:1099-1112.

van Duinkerken, G., M. C. J. Smits, G. Andrè, L. B. J. Šebek, and J. Dijkstra. 2011. Milk urea concentration as an indicator of ammonia emission from dairy barn under restricted grazing. J. Dairy Sci. 94:321-335.

Wattiaux, M. A., M. J. Aguerre, and J. M. Powell. 2011. Background and overview on the contribution of dairy nutrition to addressing environmental concerns in Wisconsin: phosphorus, nitrogen (ammonia) and methane. Pages 111-139 in La Ganadéría Ante el Agotamiento de los Paradigas Dominantes. Vol. 1. C. F. M. Álvarez, ed. Universidad Autoónoma Chapingo, Chapingo, México.

Wattiaux, M. A., and K. L. Karg. 2004. Protein level for alfalfa and corn silage-based diets: II. Nitrogen balance and manure characteristics. J. Dairy Sci. 87:3492-3502.

Wattiaux, M. A., E. V. Nordheim, and P. Crump. 2005. Statistical evaluation of factors and interactions affecting dairy herd improvement milk urea nitrogen in commercial Midwest dairy herds. J. Dairy Sci. 88:3020-3035.

Wisconsin Department of Natural Resources (WI-DNR). 2010. Beneficial Management Practices for Mitigating Hazardous Air Emissions from Animal Waste in Wisconsin. Accessed June 24, 2011. http://dnr.wi.gov/air/agWasteBMPs.html. 